\title{
Effectiveness of Nursing Guidelines Regarding Self-Care Strategies for Patients with External Skeletal Fixation
}

\author{
Rowan Mohamed El-Sayed Morsy ${ }^{1}$, Hala Abd El-Salam Sheta ${ }^{2}$ and Rasha Fathy Mohamed ${ }^{\mathbf{3}}$ \\ (1) Clinical instructor of Medical Surgical Nursing, Faculty of Nursing, Benha University, Egypt, (2) \\ Assistant Professor of Medical Surgical Nursing, Faculty of Nursing, Benha University, Egypt and (3) \\ Lecturer of Medical Surgical Nursing, Faculty of Nursing, Benha University, Egypt
}

\begin{abstract}
Background: External skeletal fixator is an important aspect of fracture management. Patients with external fixation device have limited activity of daily livings and often have negative effects on their self-care abilities. The aim of the study: Was to evaluate the effectiveness of nursing guidelines regarding self-care strategies for patients with external skeletal fixation. Research design: Quasi experimental research design was used to conduct the aim of this study. Setting: The study was conducted in the orthopedic department and outpatient clinics for orthopedics affiliated to Benha University Hospital, Benha, Egypt. Sample: Convenience sample of all available patients were taken from both sexes, their age ranged from 20 to 60 years old during six months $(n=55)$. Tools: Three tools were used; (1) Patients' interviewing questionnaire (2) Barthel Index (3) Pain assessment scale. Results: There were high statistically significance regarding the overall knowledge about the skeletal system, fracture, orthopedic fixator and self-care at pre and post implementation of guidelines, there were highly statistical differences of patients' reported practice regarding external skeletal fixation, there was positive improvement regarding patients' independency in activities of daily living and also, self-care improved significantly after applying of guidelines. Finally there were statistically significant differences regarding all items of pain assessment between pre, immediate, and one moth post guidelines implementation. Conclusion: The mean patients' knowledge and practice scores after implementation of nursing guidelines were higher than as compared to before regarding self-care strategies for patients with external skeletal fixation. Recommendations: Ongoing educational and training programs are needed for patients with external fixation regarding self-care strategies to reduce and prevent complications and apply the program on large sample selected from orthopedic department at Benha University Hospital.
\end{abstract}

Key words: External skeletal fixation, Nursing guidelines, Patients, self-care strategies.

\section{Introduction}

External fixators are used to manage fractures with soft tissue damage. External fixation involves the surgical insertion of pins through the skin and soft tissues into and through the bone. A metal external frame is attached to these pins and is designed to hold the fracture in proper alignment to enable healing to occur. Advantages of external fixation include immediate fracture stabilization, minimization of blood loss, increased patient comfort, improved wound care, promotion of early mobilization and weight bearing on the affected limb, and active exercise of adjacent uninvolved joints (Hinkle, \& Cheever, 2018). 


\section{Rowan Mohamed El-Sayed Morsy, Hala Abd El-Salam Sheta, Rasha Fathy Mohamed}

External fixator types divide into several different subcategories, including uniplanar, multiplanar, unilateral, bilateral, and circular fixators. By adding pins in different planes (i.e., placed perpendicular to each other), one can create a multiplanar construct. Uniplanar fixation devices are fast and easy to apply but are not as sturdy as multiplanar fixation. Bilateral frames are created when the pins are on both sides of the bone and can also add additional stability. Circular fixators have gained popularity with limb lengthening procedures but are especially effective at allowing the patient to weight bear and maintain some joint motion during the treatment. They are more difficult to apply and use smaller gauge pins and more of them to distribute the weight (Hadeed, Werntz \&Varacallo 2019).

Indications for bone fixation include acute fracture management, malunion, nonunion, and bone loss due to infection and tumor. The technique varies dependent on the surgeon's expertise and available resources. In lowincome or middle-income countries, the resources may be limited. The surgeon should survey the available equipment including implants, drills, and x-rays (Kozin, 2019).

Complications that can occur with external fixation treatment include: Pin site infection, Osteomyelitis, Frame or pin/wire failure or loosening, Malunion, Non-union, Soft-tissue impalement, Neurovascular injury, compartment syndrome, and refracture around pin (Shah, et al., 2019). Contraindications for bone fixation include: missing consent to surgery by the conscious patient, lifethreatening general condition by other prioritized injuries (Kamin, et al., 2020).
Self-care deficits occur when a portion of the body is immobilized. The nurse encourages the patient to participate actively in personal care and to use assistive devices safely. The nurse assist patient in identifying areas of self-care deficit and in developing strategies to achieve independence in Activities of Daily Living (ADLs) (Hinkle, \& Cheever, 2018).

Activities of daily living, often termed physical ADLs or basic ADLs, include the fundamental skills typically needed to manage basic physical needs, comprised the following areas: grooming/personal hygiene, dressing, toileting/continence,transferring/ambulating, and eating. Basic ADLs are generally categorized separately from Instrumental Activities of Daily Living (IADLs), which include more complex activities related to independent living in the community (e.g., managing finances and medications) (Mlinac, \& Feng, 2016).

Many studies recommended the importance of knowledge and practices for these patients, (khorais, Ebraheim, \& Barakat, 2018) stated that, self-care program intervention has a positive effect on patients' knowledge, practice, and physical health. Furthermore (Sayed, et al., 2019) emphasize the importance of providing written nursing instruction booklet for these patients and replication of the study on a large probability sample acquired from different geographical area in Egypt to figure out the main aspects of this problem.

\section{Significance of the study}

Around the world, 234 million surgical procedures are performed each year. Therefore, surgical site infection rate in orthopaedic surgery and its consequences still remain a 
major problem. Representing a heavy psychological and financial burden (Tucci, et al., 2019).

Worldwide, Cooper \& Gosnell, 2018 estimated that the total number of hip fractures will increase from 1.26 million in 1990 to 2.6 million by 2025 and to 4.5 million by 2050 (Farouk et al., 2017). In the United States, 5.6 million fractures occur each year, corresponding to a $2 \%$ incidence. Almost 6000 fractures were treated in an orthopedic trauma unit in Edinburgh, Scotland, in one year. The overall fracture incidence in the Scottish case series was $1.13 \%$ in men and $1.16 \%$ in women (Gouda, 2017).

In Egypt, based on different studies the agerelated fractures are projected to increase nationally from 2.1 million in 2005 to more than 3 million fractures in 2025, solely on the basis of growth in the elderly population most at risk. Fracture incidence increased with age in both sexes, but age-adjusted rates were $49 \%$ greater among the women (Amin, et al., 2014).

\section{Aim of the study:}

The study aimed to evaluate the effectiveness of nursing guidelines regarding self-care strategies for patients with external skeletal fixation through: 1-Assessing patients' level of knowledge and practice regarding external skeletal fixation pre- implementation of selfcare strategies. 2-Developing and implement self-care strategies for patients with external skeletal fixation based on their needs assessment. 3- Evaluating the effectiveness of self-care strategies on patients' level of knowledge and practice regarding external skeletal fixation post- nursing guidelines.

\section{Research hypothesis}

The following research hypothesis was formulated to fulfill the aim of the study: The patients' knowledge and practice will be improved positively after the implementation of health educational guidelines regarding selfcare strategies for patients with external skeletal fixation.

\section{Subjects and Methods}

Research design

Quasi- experimental research design was utilized to achieve the study's aim.

\section{Study setting}

The study was conducted in the orthopedic department and outpatient clinics for orthopedics affiliated to Benha University Hospital, Benha Egypt.

\section{Subject}

Convenience sample of all available patients (55) from both sexes who admitted in the above mentioned setting during six months were included in this study from both sexes, their age ranged from 20 to 60 years old and willing to participate in the study.

\section{Data Collection Tools}

Three tools were used to collect data for this study:

Tool I - Patients' interviewing questionnaire:

This tool was designed by the researcher. It was translated into Arabic language after reviewing recent relevant literatures and scientific references. It was adapted from (Dirksen, 2011; Williams, \& Hopper, 2011; White, Duncan, \& Baumle, 2013; Velazquez, Bell, \&Armstrong, 2015; Linton, 2016; khorais, Ebraheim, \& 


\section{Rowan Mohamed El-Sayed Morsy, Hala Abd El-Salam Sheta, Rasha Fathy Mohamed}

Barakat , 2018). It involved the following three parts to cover the following data:

\section{Part (1): Patients , Socio demographic} characteristics: This part concerned with the assessment of patients' socio-demographic characteristics related to their age, gender, marital status, educational level, and occupation, residence, and patients' medical diagnosis.

Part (2): Patients' Knowledge: aimed to assess patients' knowledge about patient's selfcare derived from Orem items.

\section{Scoring system:}

All knowledge variables were multiple choice questions; two scoring levels for questions were used. Each correct answer was scored (1), each incorrect answer was scored (zero). The total score for knowledge was (35). The knowledge scores were converted into a percent and categorized as follows: $\geq 70 \%$ was considered a satisfactory level of knowledge (24.5 degrees or more), $<70 \%$ was considered as an unsatisfactory level of knowledge (Less than 24.5 degrees).

Part (3): Patient's practice checklist (reported practice): It aimed to assess patients' practice regarding wound/pin site care, this tool was adopted from Khadka (2012), the checklist included (19) steps related to wound/pin site care.

\section{Scoring system:}

One grade was given for each step that done correctly, zero for the step that done incorrectly or not done. The total level of patients' practice score was (19); total practice scores were converted into a percent and categorized as follows: $\geq 70 \%$ was considered an adequate level of practice (13.3 scores or more), <70\% was considered as an inadequate level of practice (Less than 13.3 scores).

\section{Tool II- Barthel Index:}

It was adopted from ( Donna, Cech, \& Suzanne , 2012) to measure performance in Activities of Daily Living ADL (i.e., feeding oneself, bathing, dressing, grooming, and the ability to move) on a scale of 0 to 100 ( 0 , very dependent; 100, independent).

\section{Scoring system}

Full credits have score (100) when patient not need minimal help or supervision during performance and physically independent, while a score of (75-90) was given when patient mildly disabled, subsequently a score of (5070) was given when patient moderately disabled, while a score of (25-45) severely disabled and a score of (0-20) was given when patient very severely disabled and cannot perform activities of daily living.

Tool III- Pain assessment scale: It was adopted from (Benjamin, \& Charles, 2019). The Numeric Pain Rating Scale (NPRS) is uni dimensional measure to assess the intensity of pain levels for patients with external skeletal fixation. The NPRS is a best reflects the intensity patient pain. The common format is a horizontal bar or line .It contains 11-point ranges from ' 0 ' representing (no pain) to ' 10 ' representing the other pain extreme (e.g. "pain as bad as the patient can imagine" or "worst pain imaginable").

\section{Scoring system}

The values on the pain scale correspond to the pain levels as follows: 0 was considered "no pain". 1-3 was considered "mild pain". 4-6 was considered "moderate pain". 7-10 was considered "severe pain". 
*Self-care strategies booklet: It was designed by the researcher and adapted from (Taylor, Katherine Renpenning \& Renpenning ,2011; Gulanick et al., 2021; Dan \& Kemper, 2014; Sud\& Ranjan, 2018; Hadeed ,Werntz \& Varacallo, 2019). It aimed to improve patients' knowledge and practice related to self-care regarding external skeletal fixation. It includes the following items: external fixation operation (definition, indications, types, preparation, post-operative instructions, medication, and follow up), physical exercises, principles of external fixation device protection, pain management strategies, using safety measures, drug selfadministration, weight reduction, stress management strategies, overcoming negative thoughts, increasing social activities.

\section{Tools validity:}

The face and content validity were ascertained for comprehensiveness, relevance, simplicity, clarity and ambiguity through a jury of five experts from medical surgical nursing department, faculty of nursing, Benha University (two professor and three assistant professors). Also a prepared developed guidelines which covered all items related to (self-care strategies for patients with external fixation) based on newest current literature was revised by the same experts and all recommended modifications were done.

Tools reliability:

Reliability was testing statistically to assure that the tool were reliable before data collection. Cronbach's alpha for knowledge $0.74 \%$ and for reported practice was $0.78 \%$, for Barthel Index $0.8 \%$ and for pain was $0.83 \%$.

\section{Ethical considerations:}

Official permissions for data collection were generated from hospital directors and head managers of the orthopedic department at Benha university hospital by the submission of a formal letter from the dean of faculty of nursing at Benha University. Once the researcher was granted approval, patients' approval was taken after an explanation the aim of the study; they was also informed that their participation is optionally, and that they have the right to withdraw at any time without any consequences. Then, verbal consent was obtained from each participants enrolled into the study. The researcher was assured maintaining anonymity and confidentiality of data. All information was gathered used only for their benefit and for the purpose of the study.

\section{Pilot study:}

Pilot study was conducted on 6 patients $(10 \%)$ of all patients at orthopedic department and outpatients clinics in order to test the clarity and applicability of the study tools and the guidelines, to estimate time needed for filling the questionnaire as well as to identify any possible obstacles that may hinder data collection. According to the results of pilot study some modifications were done as needed. Patients involved in the pilot study were excluded from the main study. The pilot study was done two weeks before starting the study.

\section{Fieldwork:}

Data collection of the current study was carried out through six months, from the beginning of February, 2020 to end of March 2020 and then resumed from August, 2020 to 


\section{Rowan Mohamed El-Sayed Morsy, Hala Abd El-Salam Sheta, Rasha Fathy Mohamed}

end of November, 2020 because of Covid 19 pandemic. The process of data collection was achieved through: (pre-test): before implementing guidelines to have baseline assessment about patients' level of knowledge and practice. (Post-test): immediately and after one month from implementation of guidelines. The tools were filled three times; the first time before the guidelines implementation, the second time immediately after guidelines implementation, the third time after one month from guidelines implementation.

The study was conducted through three phases:

\section{Assessment Phase:}

It was carried out for all studied patients by the researcher to collect baseline data regarding patients' knowledge and practice about external skeletal fixation. The researcher attended the clinical setting three days per week during morning and afternoon shifts and interviewed each patient to collect baseline data on socio- demographic data, medical data and knowledge assessment sheet using (Tool I ) self-care and independence level using (Tool II). All the studied patients were reported practice using (Tool I part 3), and measuring pain intensity using (Tool III).This interview took about 20 to 30 minutes.

\section{The implementation phase:}

The implementation phase included the following steps:

1. The guidelines implementation was conducted in 4 sessions. Each session lasted about 30 minutes, including periods of discussion according to the patients' progress and feedback. 2. Different teaching and learning methods were used during the sessions which included; group discussions, demonstration and re-demonstration, to learn patients about external skeletal fixation. 3.The instructional colored booklet was given to each patient under the study in order to help for reviewing and support teaching it was written in a simple Arabic language and supplemented by photos and illustrations to help the patient understanding of the content. 4. At the beginning of the first session, patients were oriented regarding the guidelines contents, its purpose and its impact on his condition. Patients were informed about the time of the next session at the end of the sitting.5. Each session was started by a summary about what has been discussed in the previous session and the objectives of the new session, using simple Arabic language, also, the session ended by a summary of its contents and feedback from the patients was obtained to ensure that he/ she got the maximum benefit.

\section{Evaluation Phase:}

It aimed to evaluate the effectiveness of nursing guidelines on the patients' knowledge and practice regarding self-care strategies for patients with external skeletal fixation. It was based on the finding of differences between pre and post implementation of the performing guidelines. The evaluation was done by using the same tools of the pretest through the following phases:

Phase 1: Immediately post-test and $1^{\text {st }}$ month evaluation was performed after implementing the guidelines to evaluate the effectiveness of the self-care strategies on patients' knowledge and practices. An evaluation was done by using a (tool I \& II) in order to compare the change in the studied patients' knowledge and practices.

Phase 2: Evaluation was done in the $1^{\text {st }}$ month of follow up post guidelines implementation to 
evaluate the effectiveness of the self-care strategies on patients' pain level by using a (tool III).

\section{Data Analysis}

The collected data were organized, categorized, tabulated and analyzed using the number and percentage distribution. Statistical analysis was computed by Statistical Package for Social Sciences (SPSS 20.0). Data were presented using descriptive statistics in the form of percentages, mean degree and standard deviation (SD). Chi square test $\left(\mathrm{X}^{2}\right)$ were used for comparisons between qualitative variables to find out relations. F (ANOVA test) used to differentiate between quantitative data of the same group before and after implementation of health educational guidelines. Statistical significance was considered at p-value $<0.05$.

\section{Results:}

Table (1) shows the distribution of the studied patients' according to their socio-demographic characteristics. It was observed from the table that $50.9 \%$ of studied patients' aged between $30-40$ years old with mean age of $38.4 \pm 2.78$ years; males were more prevalent and constituted $87.3 \%$ of the patients'. Concerning marital status, it was found that $78.2 \%$ of them were married; regarding their educational level more than half of them $58.2 \%$ were secondary education. Moreover, it was observed that the majority of studied patients' $87.3 \%$ were workers and more than half of them $58.2 \%$ resided in rural areas

Table (2) shows the overall patients' knowledge about the skeletal system, fracture, orthopedic fixator and self-care. It revealed that, $25.5 \%$ of the studied patients' knowledge about the skeletal system were satisfactory at pre, while $80 \%$ of them were satisfactory at immediately post guidelines implementation and $72.7 \%$ were satisfactory post $1^{\text {st }}$ month implementation of health educational guidelines. Regarding Knowledge about the fractures there were $21.8 \%$ were satisfactory at pre and they improved in their knowledge immediate post patients' guidelines implementation to $87.3 \%$, while return to decline to $81.8 \%$ of them were satisfactory post $1^{\text {st }}$ month implementation of health educational guidelines. There were about $12.7 \%$ of patients' had satisfactory knowledge regarding the orthopedic fixator at pre, and $90.9 \%$ of them were satisfactory in their knowledge immediate post patients' guidelines implementation. Then slightly decreased to $83.6 \%$ in $1^{\text {st }}$ month post guidelines implementation. As regard their knowledge about self-care at pre only $9.1 \%$ of them were satisfactory, while most of them 90.9\% were satisfactory immediate post implementation of guidelines, then slightly decreased in their knowledge to $85.5 \%$ in $1^{\text {st }}$ month post guidelines implementation. There were high statistically significance regarding the overall knowledge about external skeletal fixation at pre, immediate post and in $1^{\text {st }}$ month post guidelines implementation at $\mathrm{p}<0.001$.

Table (3) shows the total mean score and standard deviation of patients' reported practice regarding care of external skeletal fixation pre and post guidelines implementation. It noticed that, improved from $3.14 \pm 4.69$ pre guidelines implementation to $11.10 \pm 8.36$ immediate post guidelines implementation. On the other hand, the mean score of practice about care of external skeletal fixation were decline on $1^{\text {st }}$ month post guidelines implementation to $9.98 \pm$ 10.9 respectively. In addition, there were highly statistical differences between their mean scores 


\section{Rowan Mohamed El-Sayed Morsy, Hala Abd El-Salam Sheta, Rasha Fathy Mohamed}

pre guidelines implementation as compared to post guidelines implementation $\mathrm{p}<0.001$.

Figure (1) illustrates that, total independency in activities of daily living among studied patients' was $58.2 \%$ had a sever disability, while their total independency immediately post implementation of guidelines was $52.7 \%$ had mild disability. In addition their total independency in activities of daily living post $1^{\text {st }}$ month of implementation guidelines was $58.2 \%$ had mild disability. There was an improvement in total independency in activities of daily living among studied patients'.

Figure (2) illustrates that, $54.5 \%$ of the studied patients' had moderate total pain score at pre implementation of guidelines, while $58.2 \%$ of them had mild pain immediately post implementation of guidelines, and at post $1^{\text {st }}$ month of guideline implementation $54.5 \%$ of them had mild pain.in addition there was an improvement regarding to total pain score at pre, immediate post and $1^{\text {st }}$ month post implementation of health educational guidelines

Table (4) shows relation between overall patients' knowledge and their socio-demographic characteristics. It revealed that, there was highly statistical significant relation between socio-demographic characteristics of the studied patients' score and their level of total knowledge regarding age and educational level, during preguidelines implementation as $p<0.001$, as well as their socio-demographic characteristics and their level of total knowledge pre-guidelines implementation as $\quad \mathrm{p}<0.05 \quad$ regarding occupation. While there was no statistical significant relation between socio-demographic characteristics of the studied patients' score and their level of total knowledge regarding gender, marital status, residence, and suffering from chronic disease pre as well as post guidelines implementation as $\mathrm{p}>0.05$.

Table (5) shows that there was high significant statistical positive correlation between patients' knowledge , reported practice, level of independency and pain score at pre and post guidelines implementation $(p<0.001)$. 
Table (1): Number and percentage distribution of socio-demographic characteristics of the studied patients' $(\mathrm{n}=\mathbf{5 5})$.

\begin{tabular}{|c|c|c|}
\hline \multirow[t]{2}{*}{ Socio-demographic data } & \multicolumn{2}{|c|}{ Total $(n=55)$} \\
\hline & $\mathbf{N}$ & $\%$ \\
\hline \multicolumn{3}{|l|}{ Age (Year) } \\
\hline $20-<30$ & 8 & 14.5 \\
\hline $30-<40$ & 28 & 50.9 \\
\hline $40-<50$ & 11 & 20 \\
\hline$\geq 50$ & 8 & 14.5 \\
\hline $\begin{array}{l}\text { Range } \\
x^{-} \text {S.D }\end{array}$ & \multicolumn{2}{|c|}{$22-60$} \\
\hline Gender & & \\
\hline Male & 48 & 87.3 \\
\hline Female & 7 & 12.7 \\
\hline \multicolumn{3}{|l|}{ Marital Status } \\
\hline Single & 8 & 14.6 \\
\hline Married & 43 & 78.2 \\
\hline Widow & 2 & 3.6 \\
\hline Divorced & 2 & 3.6 \\
\hline \multicolumn{3}{|l|}{ Education level } \\
\hline Illiterate & 4 & 7.3 \\
\hline Reads and writes & 7 & 12.7 \\
\hline Secondary education & 32 & 58.2 \\
\hline University education & 12 & 21.8 \\
\hline Postgraduate education & 0 & 0.0 \\
\hline \multicolumn{3}{|l|}{ Occupation } \\
\hline Working & 48 & 87.3 \\
\hline Not working & 7 & 12.7 \\
\hline \multicolumn{3}{|l|}{ If yes, what is the nature of work? $(n=48)$} \\
\hline Office work & 15 & 31.2 \\
\hline Manual work & 33 & 68.8 \\
\hline \multicolumn{3}{|l|}{ Place of residence } \\
\hline Rural & 32 & 58.2 \\
\hline Urban & 23 & 41.8 \\
\hline
\end{tabular}


Table (2): Total patients' knowledge about the skeletal system, fracture, orthopedic fixator and self-care at pre and post implementation of health educational guidelines $(n=55)$.

\begin{tabular}{|c|c|c|c|c|c|c|c|c|c|c|c|c|c|c|}
\hline \multirow[t]{4}{*}{ Patients' knowledge } & \multirow{2}{*}{\multicolumn{4}{|c|}{ Pre test }} & \multicolumn{8}{|c|}{ Post test } & \multicolumn{2}{|c|}{$\begin{array}{c}\text { Friedman } \\
\text { test }\end{array}$} \\
\hline & & & & & \multicolumn{4}{|c|}{ Immediate } & \multicolumn{4}{|c|}{$1^{\text {st }}$ month } & \multirow[t]{3}{*}{$\mathbf{F}$} & \multirow{3}{*}{$\begin{array}{c}\text { p- } \\
\text { value }\end{array}$} \\
\hline & \multicolumn{2}{|c|}{$\begin{array}{l}\text { Satisfact } \\
\text { ory }\end{array}$} & \multicolumn{2}{|c|}{$\begin{array}{c}\text { Unsatisfa } \\
\text { ctory }\end{array}$} & \multicolumn{2}{|c|}{$\begin{array}{l}\text { Satisfact } \\
\text { ory }\end{array}$} & \multicolumn{2}{|c|}{$\begin{array}{c}\text { Unsatisfa } \\
\text { ctory }\end{array}$} & \multicolumn{2}{|c|}{$\begin{array}{c}\text { Satisfactor } \\
\mathbf{y}\end{array}$} & \multicolumn{2}{|c|}{$\begin{array}{c}\text { Unsatisfac } \\
\text { tory }\end{array}$} & & \\
\hline & $\mathbf{N}$ & $\%$ & $\mathbf{N}$ & $\%$ & $\mathbf{N}$ & $\%$ & $\mathbf{N}$ & $\%$ & $\mathbf{N}$ & $\%$ & $\mathbf{N}$ & $\%$ & & \\
\hline $\begin{array}{l}\text { Knowledge about the skeletal } \\
\text { system }\end{array}$ & $\begin{array}{l}1 \\
4\end{array}$ & $\begin{array}{c}25 . \\
5\end{array}$ & $\begin{array}{l}4 \\
1\end{array}$ & $\begin{array}{l}74 . \\
5\end{array}$ & $\begin{array}{l}4 \\
4\end{array}$ & 80 & 11 & 20 & 40 & 72.7 & 15 & 27.3 & 17.73 & $.000 * *$ \\
\hline $\begin{array}{l}\text { Knowledge about the } \\
\text { fractures }\end{array}$ & $\begin{array}{l}1 \\
2\end{array}$ & $\begin{array}{c}21 . \\
8\end{array}$ & $\begin{array}{l}4 \\
3\end{array}$ & $\begin{array}{c}78 . \\
2\end{array}$ & $\begin{array}{l}4 \\
8\end{array}$ & $\begin{array}{l}87 . \\
3\end{array}$ & 7 & $\begin{array}{l}12 . \\
7\end{array}$ & 45 & 81.8 & 10 & 18.2 & 18.71 & $.000 * *$ \\
\hline $\begin{array}{l}\text { Knowledge about the } \\
\text { orthopedic fixator }\end{array}$ & 7 & $\begin{array}{c}12 . \\
7\end{array}$ & $\begin{array}{l}4 \\
8\end{array}$ & $\begin{array}{c}87 . \\
3\end{array}$ & $\begin{array}{l}5 \\
0\end{array}$ & $\begin{array}{l}90 . \\
9\end{array}$ & 5 & 9.1 & 46 & 83.6 & 9 & 16.4 & 21.30 & $.000 * *$ \\
\hline Knowledge about self-care & 5 & 9.1 & $\begin{array}{l}5 \\
0\end{array}$ & $\begin{array}{l}90 . \\
9\end{array}$ & $\begin{array}{l}5 \\
0\end{array}$ & $\begin{array}{l}90 . \\
9\end{array}$ & 5 & 9.1 & 47 & 85.5 & 8 & 14.5 & 21.61 & $.000 * *$ \\
\hline
\end{tabular}

$* *$ Highly significant at $\mathrm{p}<0.01$

Table (3): Total patients' practice regarding external skeletal fixation at pre and post implementation of health educational guidelines $(n=55)$.

\begin{tabular}{|c|c|c|c|c|c|c|c|c|}
\hline \multirow[t]{3}{*}{$\begin{array}{c}\text { Levels of total } \\
\text { reported practice }\end{array}$} & \multirow{2}{*}{\multicolumn{2}{|c|}{ Pre test }} & \multicolumn{4}{|c|}{ Post test } & \multicolumn{2}{|c|}{$\begin{array}{c}\text { Friedman } \\
\text { test }\end{array}$} \\
\hline & & & \multicolumn{2}{|c|}{ Immediate } & \multicolumn{2}{|c|}{$1^{\text {st }}$ month } & \multirow[t]{2}{*}{$\mathbf{F}$} & \multirow{2}{*}{$\begin{array}{c}\text { p- } \\
\text { value }\end{array}$} \\
\hline & $\overline{\mathbf{N}}$ & $\%$ & $\overline{\mathbf{N}}$ & $\%$ & $\overline{\mathbf{N}}$ & $\%$ & & \\
\hline Adequate & 8 & 14.5 & 44 & 80 & 40 & 72.7 & \multirow{4}{*}{21.87} & \multirow{4}{*}{$\begin{array}{c}.00 * * \\
*\end{array}$} \\
\hline Inadequate & 47 & 85.5 & 11 & 20 & 15 & 27.3 & & \\
\hline Range & \multicolumn{2}{|c|}{$0-10$} & \multicolumn{2}{|c|}{$5-13$} & \multicolumn{2}{|c|}{$4-11$} & & \\
\hline $\mathbf{x}^{-}$S.D & \multicolumn{2}{|c|}{$3.14 \pm 4.69$} & \multicolumn{2}{|c|}{$11.10 \pm 8.36$} & \multicolumn{2}{|c|}{$9.98 \pm 10.9$} & & \\
\hline
\end{tabular}

$* *$ Highly significant at $\mathbf{p}<\mathbf{0 . 0 1}$.

F (ANOVA test) used to differentiate between total practice towards external skeletal fixation of the same group before and after implementation of health educational guidelines 


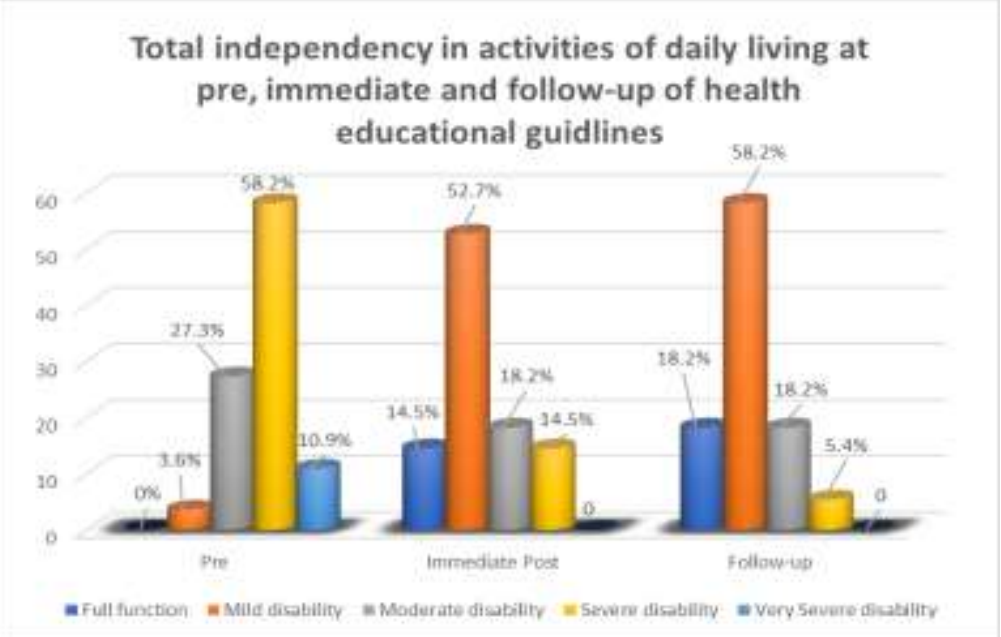

Figure (1): Total independency in activities of daily living pre and post implementation of health educational guidelines $(\mathbf{n}=\mathbf{5 5})$.



Figure (2): Total pain score at pre and post guidelines implementation $(n=55)$. 
Table (4): Relation between socio-demographic characteristics of the studied patients' and their level of total knowledge at pre and post implementation of health educational guidelines $(n=55)$.

\begin{tabular}{|c|c|c|c|c|c|c|c|c|c|c|c|c|c|}
\hline \multirow{3}{*}{\multicolumn{2}{|c|}{$\begin{array}{l}\text { Socio-demographic } \\
\text { characteristics of the } \\
\text { patients? }\end{array}$}} & \multicolumn{4}{|c|}{$\begin{array}{c}\text { Levels of total } \\
\text { knowledge at pre- } \\
\text { educational guidelines } \\
(n=55) .\end{array}$} & \multirow[t]{3}{*}{$\chi^{2}$} & \multirow{3}{*}{$\begin{array}{l}\text { P- } \\
\text { Valu } \\
\text { e }\end{array}$} & \multicolumn{4}{|c|}{$\begin{array}{c}\text { Levels of total } \\
\text { knowledge at post- } \\
\text { educational } \\
\text { guidelines }(n=55)\end{array}$} & \multirow[t]{3}{*}{$\chi^{2}$} & \multirow{3}{*}{$\begin{array}{l}\text { P- } \\
\text { Valu } \\
\text { e }\end{array}$} \\
\hline & & \multicolumn{2}{|c|}{$\begin{array}{l}\text { Satisfacto } \\
\text { ry }(n=10)\end{array}$} & \multicolumn{2}{|c|}{$\begin{array}{l}\text { Unsatisfa } \\
\text { ctory } \\
(n=45)\end{array}$} & & & \multicolumn{2}{|c|}{$\begin{array}{c}\text { Satisfact } \\
\text { ory } \\
(n=46)\end{array}$} & \multicolumn{2}{|c|}{$\begin{array}{l}\text { Unsatisfa } \\
\text { ctory } \\
(n=9)\end{array}$} & & \\
\hline & & $\mathbf{N}$ & $\%$ & $\mathbf{N}$ & $\%$ & & & $\mathbf{N}$ & $\%$ & $\mathbf{N}$ & $\%$ & & \\
\hline \multirow{4}{*}{ Age (year) } & $20-<30$ & 8 & 80 & 0 & 0.0 & \multirow[t]{4}{*}{$\begin{array}{c}16.3 \\
0\end{array}$} & \multirow[t]{4}{*}{$\begin{array}{l}.000^{*} \\
*\end{array}$} & 8 & $\begin{array}{c}17 . \\
4\end{array}$ & $\overline{0}$ & 0.0 & \multirow[t]{4}{*}{$\begin{array}{c}17.2 \\
2\end{array}$} & \multirow[t]{4}{*}{$\begin{array}{c}.000^{*} \\
*\end{array}$} \\
\hline & $30-<40$ & 2 & 20 & 26 & 57.8 & & & 28 & $\begin{array}{c}60 . \\
9\end{array}$ & 0 & 0.0 & & \\
\hline & $40-<50$ & 0 & 0.0 & 11 & 24.4 & & & 10 & $\begin{array}{c}21 . \\
7\end{array}$ & 1 & 11.1 & & \\
\hline & $\geq 50$ & 0 & 0.0 & 8 & 17.8 & & & 0 & 0.0 & 8 & 88.9 & & \\
\hline \multirow[t]{2}{*}{ Gender } & Male & 7 & 70 & 41 & 91.1 & \multirow{2}{*}{$\begin{array}{c}3.02 \\
1\end{array}$} & \multirow[t]{2}{*}{.149} & 41 & $\begin{array}{c}89 . \\
1 .\end{array}$ & 7 & 77.8 & \multirow{2}{*}{$\begin{array}{c}2.74 \\
5\end{array}$} & \multirow[t]{2}{*}{.161} \\
\hline & Female & 3 & 30 & 4 & 8.9 & & & 5 & $\begin{array}{c}10 . \\
9\end{array}$ & 2 & 22.2 & & \\
\hline \multirow[t]{4}{*}{ Marital status } & Single & 2 & 20 & 6 & 13.3 & \multirow[t]{4}{*}{$\begin{array}{c}2.40 \\
1\end{array}$} & \multirow[t]{4}{*}{.177} & 8 & $\begin{array}{c}17 . \\
4\end{array}$ & $\overline{0}$ & 0.0 & \multirow[t]{4}{*}{$\begin{array}{c}3.23 \\
1\end{array}$} & \multirow[t]{4}{*}{.130} \\
\hline & Married & 6 & 60 & 37 & 82.3 & & & 35 & $\begin{array}{c}76 . \\
1\end{array}$ & $\overline{8}$ & 88.9 & & \\
\hline & Divorced & 1 & 10 & 1 & 2.2 & & & 1 & 2.2 & 1 & 11.1 & & \\
\hline & Widowed & 1 & 10 & 1 & 2.2 & & & 2 & 4.3 & 0 & 0.0 & & \\
\hline \multirow{4}{*}{$\begin{array}{l}\text { Educational } \\
\text { level }\end{array}$} & Illiterate & 0 & 0.0 & 4 & 8.9 & \multirow{4}{*}{$\begin{array}{c}14.1 \\
5\end{array}$} & \multirow{4}{*}{$\begin{array}{c}.001 * \\
*\end{array}$} & 0 & 0.0 & $\overline{4}$ & 44.4 & \multirow{4}{*}{$\begin{array}{c}16.8 \\
7\end{array}$} & \multirow{4}{*}{$\begin{array}{l}.000^{*} \\
*\end{array}$} \\
\hline & $\begin{array}{l}\text { Reads } \\
\text { and } \\
\text { writes }\end{array}$ & 0 & 0.0 & 7 & 15.6 & & & 2 & 4.3 & 5 & 55.6 & & \\
\hline & $\begin{array}{c}\text { Secondar } \\
\mathrm{y} \\
\text { education }\end{array}$ & 0 & 0.0 & 32 & 71.1 & & & 32 & $\begin{array}{c}69 . \\
6\end{array}$ & 0 & 0.0 & & \\
\hline & $\begin{array}{l}\text { University } \\
\text { education }\end{array}$ & 10 & 100 & 2 & 4.4 & & & 12 & $\begin{array}{c}26 . \\
1\end{array}$ & 0 & 0.0 & & \\
\hline Residence & Rural & 4 & 40 & 28 & 62.2 & $\begin{array}{c}2.13 \\
0\end{array}$ & .160 & 26 & $\begin{array}{c}56 . \\
5\end{array}$ & $\overline{6}$ & 66.7 & $\begin{array}{c}2.33 \\
0\end{array}$ & .154 \\
\hline & Urban & 6 & 60 & 17 & 37.8 & & & 20 & $\begin{array}{c}43 . \\
5\end{array}$ & 3 & 33.3 & & \\
\hline Occupation & Working & 8 & 80 & 40 & 88.9 & 9.02 & $.035 *$ & 46 & 100 & 2 & 22.2 & 10.3 & $.029 *$ \\
\hline & $\begin{array}{c}\text { Not } \\
\text { working }\end{array}$ & 2 & 20 & 5 & 11.1 & 3 & & 0 & 0.0 & 7 & 77.8 & 7 & \\
\hline $\begin{array}{l}\text { Suffering } \\
\text { from chronic }\end{array}$ & Yes & 6 & 60 & 18 & 40 & $\begin{array}{c}1.96 \\
5\end{array}$ & .274 & 19 & $\begin{array}{c}41 . \\
3\end{array}$ & 5 & 55.6 & $\begin{array}{c}1.86 \\
6\end{array}$ & .284 \\
\hline disease & No & 4 & 40 & 27 & 60 & & & 27 & $\begin{array}{c}58 . \\
7\end{array}$ & 4 & 44.4 & & \\
\hline
\end{tabular}

In significant at $\mathbf{p}>\mathbf{0 . 0 5}$.

*Significant at $p<0.05$.

$* *$ Highly significant at $\mathrm{p}<0.01$.

$\chi^{2}$ : Chi square test 
Table (5): Correlation between patients' knowledge, reported practice, level of independency and pain score at pre and post implementation of guidelines $(n=55)$.

\begin{tabular}{|c|c|c|c|c|c|c|c|c|c|c|}
\hline \multicolumn{2}{|l|}{ Variables } & \multicolumn{3}{|c|}{ Total knowledge } & \multicolumn{3}{|c|}{ Total reported practice } & \multicolumn{3}{|c|}{ Levels of independency } \\
\hline & & Pre & Post & $\begin{array}{c}\text { Follow- } \\
\text { up }\end{array}$ & Pre & Post & $\begin{array}{c}\text { Follow } \\
\text {-up }\end{array}$ & Pre & Post & $\begin{array}{c}\text { Follow- } \\
\text { up }\end{array}$ \\
\hline $\begin{array}{l}\text { Total } \\
\text { knowledge }\end{array}$ & $\begin{array}{l}\mathbf{r} \\
\mathbf{p}\end{array}$ & & & & & & & & & \\
\hline $\begin{array}{l}\text { Total reported } \\
\text { practice }\end{array}$ & $\begin{array}{l}\mathbf{r} \\
\mathbf{p}\end{array}$ & $\begin{array}{c}.407 \\
.000 * *\end{array}$ & $\begin{array}{c}.414 \\
.000 * *\end{array}$ & $\begin{array}{c}.422 \\
.000 * *\end{array}$ & & & & & & \\
\hline $\begin{array}{l}\text { Levels of } \\
\text { independency }\end{array}$ & $\begin{array}{l}\mathbf{r} \\
\mathbf{p}\end{array}$ & $\begin{array}{l}.244 \\
.012 *\end{array}$ & $\begin{array}{c}.257 \\
0.01 *\end{array}$ & $\begin{array}{l}.254 \\
.012 *\end{array}$ & $\begin{array}{l}.275 \\
.009 * *\end{array}$ & $\begin{array}{c}.357 \\
.000 * *\end{array}$ & $\begin{array}{c}.388 \\
.000 * *\end{array}$ & & & \\
\hline $\begin{array}{l}\text { Total pain } \\
\text { score }\end{array}$ & $\begin{array}{l}\mathbf{r} \\
\mathbf{p}\end{array}$ & $\begin{array}{l}-.211 \\
.037 *\end{array}$ & $\begin{array}{l}-.228 \\
.025 *\end{array}$ & $\begin{array}{l}-.236 \\
.024 *\end{array}$ & $\begin{array}{l}-.279 \\
.005^{* *}\end{array}$ & $\begin{array}{l}-.290 \\
.003 * *\end{array}$ & $\begin{array}{l}-.301 \\
.001 * *\end{array}$ & $\begin{array}{l}-.364 \\
.000 * *\end{array}$ & $\begin{array}{l}-.371 \\
.000 * *\end{array}$ & $\begin{array}{c}-.385 \\
.000 * *\end{array}$ \\
\hline
\end{tabular}

Discussion

Regarding to patients' socio demographic characteristics; the results of the current study reported that half of the studied patients' aged from 30 to 40 years. This result was in the same line with Khorais , Ebraheim, \& Barakat (2018) who stated in his study entitled "SelfCare Program: Quality of Life and Satisfaction among Patients with External Skeletal Fixation" that more than half of patients aged from 20 to 40 years. Therefore this finding disagreed with Modin, Ramos \& Stomberge (2009), who conducted a study entitled "Postoperative impact of daily life after primary treatment of proximal/ distal tibia fracture with Ilizarov external fixation" and mentioned that all the patients' aged from 18 to 80 years old. From the researcher point of view this attributed to several factors such as, criteria of selection of sample and increase probability of accidents are usually occur in the former age brackets or even more.

As for gender, the results of the present study revealed that the majority of patients' were males and more prevalent. This result was agreed with the study done by Milenković et al., (2013) whose study was about "Distal tibial pilon fractures (AO/OTA type $\mathrm{B}$, and $\mathrm{C}$ ) treated with the external skeletal and minimal internal fixation method "and reported that the more than half of patients' were male. Also, this finding was in line with Mahdian et al., (2017) who reported in their study entitled "epidemiological profile of extremity fractures and dislocations in road traffic accidents in Kashan, Iran" whose study results revealed that of the majority of cases were males. On the other hand, this finding disagreed with Xing et al., (2020) who made a study about" Factors influencing selfcare in outpatients with external fixation in China" who reported that more than half of patients' were females. Therefore, Modin, Ramos\& stomberge (2009) who found that, the majority of the studied group were females. From the researcher point of view, this could be explained in light of the known fact that men in Egypt support their families and go to work daily and are more prone to accidents.

Concerning marital status, the present study revealed that the majority of studied patients' were married, this finding were in accordance with Khorais , Ebraheim, \& Barakat (2018) 


\section{Rowan Mohamed El-Sayed Morsy, Hala Abd El-Salam Sheta, Rasha Fathy Mohamed}

who found that more than half of patients' were married. As regards to occupation the present study illustrated that two thirds of the studied patients' were manual workers. This result agreed with Sayed et al., (2019) who studied" effect of Nursing Management on Pin Site Infection Among Incidence Patients with External Fixators" who found that two third of the studied patients' were manual workers .On the other hand, this result was contradicted with Xing et al., (2020) who found that more than half of participants engaged in work that requires physical activity.

Regarding the education level the result of the current study showed that, more than half of patients' received secondary school education. This result was congruent with Wong, Chan \& Chair (2010) who reported in their study entitled" effectiveness of an educational intervention on levels of pain, anxiety and selfefficacy for patients with musculoskeletal trauma" that more than half of patients' with external fixation devices received secondary school education. This result was incongruent with Xing et al., (2020) who found that more than half of patients' had an education level of junior high school or lower. From the researcher point of view, this may be due to that the study was conducted in the governmental hospital which accommodates many numbers of patients' with low socioeconomic levels with low educational level. As regards residence; it was observed that more than half of patients' had lived in rural. The result comes in consistent with Mohamed et al., (2020) who conducted a study entitled "Nurses Performance Regarding Orthopedic Patients with External Fixation at Zagazig University Hospitals" and found that half of studied sample were live in rural. The results were similar also to findings of Suresh et al., (2008) who conducted a study entitled "The effect of smoking on pin site infection rate among patients with external skeletal fixation" and confirmed that the majority of the studied group belonged to rural. This result disagreed with Saw et al.,(2010) whose study entitled "Comparison of fracture patterns between rural and urban populations in a developing country" , they found that fractures was the main cause of admission to the hospital in the urban areas.

\section{Regarding total patients' knowledge about} the skeletal system, fracture, orthopedic fixator and self-care; the results of the present study revealed that there were high statistically significance regarding the total knowledge score about the skeletal system, fracture, orthopedic fixator and self-care at pre, post and after (one month) implementation of health educational guidelines which reflect the positive effect of the guidelines on improving patients' level of knowledge. Also similar to the present study finding, a study conducted by Khorais, Ebraheim \& Barakat (2018) they noticed that there were statistically significant differences among studied patients throughout the implementation of the self-care program in the three phases of the study (pre, immediately post and follow up program implementation) regarding their knowledge about external fixation device, pin site care, principles of device protection, pain management strategies, nutrition, and range of motion and physical exercises.

Another study conducted by Ahmed \& Abd-El Mohsen (2018) whose study entitled "Effect of compliance to the discharge instructions among patients with internal fixation for hip fracture, Journal of Nursing Education and Practice" supported the current finding and asserted that 
orthopedic patients had improvement in their knowledge after a structured education. This study finding was in same line with a study conducted by Ben-Morderchai et al., (2010) whose study entitled "Structured discharge education improves early outcome in orthopedic patients" who stated after giving educational guidelines to the study group they showed better self-care and daily living activities.

\section{Concerning to patients' practice about wound} care; the present study revealed that there were highly statistical differences regarding patients' reported practice towards external skeletal fixation (wound care). This study finding was in same line with a study conducted by Brereton (2016) who study "Pin site care the rate of local infection. Orthopedic external fixation device: Management \& Care" and confirmed that there were highly statistical differences regarding pin site care after guidelines.

Concerning patients' self-care strategy during daily living; the result of the present study revealed that, there was a significant positive improvement regarding patients' independency in activities of daily living and self-care. This finding was consistent with Cary et al., (2016) who studied "self-care and mobility following post-acute rehabilitation for older adults with hip fracture: a multilevel analysis", who mentioned in their study that independency in activities of daily living and self-care scores was improved at discharge compared with self-care and mobility at admission, respectively. This finding was supported by Alarcón et al., (2011) whose study titled "Activities of daily living after hip fracture: profile and rate of recovery during 2 years of follow-up" who found that there was improvement regarding self-care and activities of daily living in the majority of the study group.

Pertaining to patients' pain characteristics, the current study revealed that, there were statistically significant differences regarding all items of pain assessment between pre and post guidelines implementation, which reflect the importance of the guidelines. This finding was in agreement with Kodama et al., (2018) who studied"Joint distraction and early mobilization using a new dynamic external finger fixator for the treatment of fracture-dislocations of the proximal inter-phalangeal joint" who confirmed that, there were statistically significant differences regarding pain between pre and post guidelines. This finding is also supported by Ostiak \& Koczewski (2009) they studied" Pain intensity in patients treated by the external fixation".they stated that there was a statistically significant differences regarding pain.

This result was in disagreement with Milenkovic, Mitkovic \& Bumbasirevic (2006) who stated in their study entitled "External fixation of open subtalar dislocation" and documented that, pain was experienced by majority of patients. On contrary, Pollak et al., (2003) who reported in his study entitled "Outcomes after treatment of high-energy tibial plafond fractures" who found that, the average pain score of patients treated with external fixation got worse and increased. And Patterson et al., (2006) emphasized in their study entitled, "Impact of External Fixation on Adolescents: An Integrative Research Review" who found that, pain was the most problematic physical findings.

Concerning correlation between patients' knowledge, reported practice, level of 


\section{Rowan Mohamed El-Sayed Morsy, Hala Abd El-Salam Sheta, Rasha Fathy Mohamed}

independency and pain score; the results of the present study showed that there was high significant statistical positive correlation between patients' knowledge, reported practice, level of independency and pain at pre and post implementation of guidelines .This finding was in the same line with the study done by Gethin et al., (2020) in the study entitled" Evidence for person-centered care in chronic wound care: A systematic review and recommendations for practice" they found that, significant improvements were reported in patient's knowledge, pain and self-care.

This finding was also supported by Nunez et al.,(2006) whose study entitled " The effect of an educational program to improve healthrelated quality of life in patients with osteoarthritis on waiting list for total knee replacement: a randomized study" they stated that there was high significant statistical positive correlation between patient education, pain and self-care. Also these results were in the same line with Ben-Morderchai (2010) whose study entitled "Structured discharge education improves outcome in orthopedic patients", they stated that there was high significant statistical positive correlation between patients' knowledge, pain, independency and activity of daily living.

\section{Conclusion}

Overall patients' knowledge and reported practice regarding self-care strategies for patients with external skeletal fixation increased immediate post guidelines implementation and return to decline post one month, with a statistical differences between their mean scores pre guidelines implementation as compared to post guidelines implementation which may attributed to the patients need more frequent follow up. There was significant statistical relation between studied patients' independency in activities of daily living score at pre and post implementation of health educational guidelines. Also, it was noticed that, there was an improvement regarding to total pain score at pre, immediate post and $1^{\text {st }}$ month post implementation of health educational guidelines. Clearly, it was observed a positive correlation between patients' knowledge, reported practice, level of independency and their pain score at pre and post guidelines implementation regarding external skeletal fixation which supported the study hypothesis.

\section{Recommendations:}

The need for continuous educational and training programs for patients with external fixation. In addition, further researches are needed for patients' with external fixation regarding self-care strategies to reduce and prevent complications and apply it on large sample selected from orthopedic department at Benha University Hospital. Moreover, the educational intervention and patient's psychosocial support should be included in routine nursing care as a protocol before and after external skeletal fixation surgery and at the time of follow up phase. Increase patients' awareness about the importance of pin site care and periodic check up to prevent developing any complications which can effect on their quality of life by providing written nursing instruction booklet is of a great importance for patients.

\section{References}

Ahmed, M.N. \& Abd-El mohsen, A.S. (2018). Effect of compliance to the discharge instructions among patients with internal fixation for hip fracture, Journal of Nursing Education and Practice, 8 (4): 112-117. 
Alarcón, T., González, M. I., Gotor, P., Madero, R., \& Otero, A. (2011). Activities of daily living after hip fracture: profile and rate of recovery during 2 years of follow-up. Osteoporosis international, 22(5), 1609-1613.

Amin, S., Achenbach, S. J., Atkinson, E. J., Khosla, S., \& Melton iii, L. J, (2014).Trends in fracture incidence. journal of bone and mineral research, 29(3), p. 581-589.

Benjamin, J., \& Charles ,B. ,(2019). A practice of anesthesia for infants and children ,sixth edition, elsevier health science, p.10231062.

Ben-Morderchai, B., Herman, A., Kerzman, H., \& Irony, A. (2010). Structured discharge education improves early outcome in orthopedic patients. International Journal of Orthopaedic and Trauma Nursing, 14(2), 6674.

Brereton, V. (2016). Pin site care the rate of local infection. Orthopedic external fixation device: Management \& Care. Journal of Wound care, 1, 9-11.

Cary, J.R, Pan, W., Sloane, R., Bettger, J. P., Hoenig, H., Merwin, E. I., \& Anderson, R. A. (2016). Self-care and mobility following postacute rehabilitation for older adults with hip fracture: a multilevel analysis. Archives of physical medicine and rehabilitation, 97(5), 760-771.

Cooper, K., \& Gosnell, K. (2018). Adult Health Nursing E-Book. Elsevier Health Sciences.

Dan, D. Kemper, D.K. (2014). Principles of external Fixation. Available at https://ota.org/sites/files/2018-06/G11

Principles\%20of\%20External\%20Fixation.pdf. Accessed on 2 february 2020.

Dirksen, R. (2011): Medical - Surgical Nursing, 8th ed., Mosby, USA, pp.592-623.
Donna, J., Cech, D.S., Suzanne, S. (2012). Functional movement development across the life span, $3^{\text {rd }}$ edition, Elsevier health science, $p$ 88-104.

Farouk, O., Mahran, D. G., Said, H. G., Alaa, M. M., Eisa, A., Imam, H., \& Said, G. Z. (2017). Osteoporosis among hospitalized patients with proximal femoral fractures in Assiut University Trauma Unit, Egypt. Archives of osteoporosis, 12(1), 12.

Gethin, G., Probst, S., Stryja, J., Christiansen, N., \& Price, P. (2020). Evidence for person-centred care in chronic wound care: A systematic review and recommendations for practice. Journal of wound care, 29(Sup9b), S1-S22.

Gouda, R. (2017). Nurses' Performance for Orthopedic Patients with Traction or Internal Fixatio. Port Said Scientific Journal of Nursing, $\quad 4(2), \quad$ 193-2018. doi: 10.21608/pssjn.2017.33082

Gulanick, M., Faan, P. A., Myers, J. L., \& Msn, R. N. (2021). Nursing Care Plans-EBook: Nursing Diagnosis and Intervention. Available at http://www .eoj.eg. Accessed on 3 January 2021.

Hadeed, A., Werntz, R. L., \& Varacallo, M. (2019). External Fixation Principles and Overview. In StatPearls [Internet]. StatPearls Publishing.Available at https:// europepmc .org/article /NBK/ nbk 547694 . Accessed on $22 / 1 / 2021$.

Hinkle, J. L., \& Cheever, K. H. (2018). Brunner and Suddarth's textbook of medicalsurgical nursing. Wolters kluwer india Pvt Ltd. Kamin, K., Rammelt, S., Kleber, C., Marx, C., \& Schaser, K. D. (2020). External fixator: temporary fixation and soft tissue management of the ankle. Operative Orthopadie und Traumatologie, 32(5), 421-432. 


\section{Rowan Mohamed El-Sayed Morsy, Hala Abd El-Salam Sheta, Rasha Fathy Mohamed}

Khorais, A., Ebraheim, M., \& Barakat, A. (2018). Self-Care Program: Quality of Life and Satisfaction among Patients with External Skeletal Fixation. IOSR Journal of Nursing and Health Science, 7(4), 71-83.

Kodama, A., Sunagawa, T., Nakashima, Y., Shinomiya, R., Hayashi, Y., Ochi, M., \& Adachi, N. (2018). Joint distraction and early mobilization using a new dynamic external finger fixator for the treatment of fracturedislocations of the proximal interphalangeal joint. Journal of Orthopaedic Science, 23(6), 959-966.

Kozin, S. H. (2019). Bone Fixation. In Global Reconstructive Surgery (pp. 77-85). Elsevier.

Linton, A. (2016): Introduction to MedicalSurgical Nursing, $6^{\text {th }}$ ed., U.S.A., Elsevier, pp. 971-985.

Mahdian, M., Fazel, M. R., Sehat, M., Khosravi, G., \& Mohammadzadeh, M. (2017). Epidemiological profile of extremity fractures and dislocations in road traffic accidents in Kashan, Iran: a glance at the related disabilities. Archives of bone and joint surgery, 5(3), 186.

Milenkovic, S., Mitkovic, M., \& Bumbasirevic, M. (2006). External fixation of open subtalar dislocation. Injury, 37(9), 909913.

Milenković, S., Mitković, M., Micić, I., Mladenović, D., Najman, S., Trajanović, M., \& Mitković, M. (2013). Distal tibial pilon fractures (AO/OTA type B, and C) treated with the external skeletal and minimal internal fixation method. Vojnosanitetski pregled, 70(9), 836-841.

Mlinac, M. E., \& Feng, M. C. (2016). Assessment of activities of daily living, selfcare, and independence. 31(6), 506-516
Modin, M., Ramos, T., \& Stomberg, M. W. (2009). Postoperative impact of daily life after primary treatment of proximal/distal tibiafracture with Ilizarov external fixation. Journal of clinical nursing, 18(24), 3498-3506.

Mohamed, M., Mansour, N., Mohamed Taha, N., \& Moghazy, A. (2020).Nurses Performance Regarding Orthopedic Patients with External Fixation at Zagazig University Hospitals. Egyptian Journal of Health Care, 11(1), 115-126.

Nunez, M.; Nunez, E.; Segur, J.; Macule, M.D.; Quinto, L.; Hernandez, M.V. and Vilalta, C. (2006). The effect of an educational program to improve health-related quality of life in patients with osteoarthritis on waiting list for total knee replacement: a randomized study, Osteoarthritis and Cartilage,14: pp. 279285.

Ostiak, W., \& Koczewski, P. (2009). Pain intensity in patients treated by the external fixation. Chirurgia narzadow ruchu i ortopedia polska, 74(4), 228-232.

Patterson, M. (2006). Impact of external fixation on adolescents: an integrative research review. Orthopaedic Nursing, 25(5), 300-308.

Pollak, A. N., McCarthy, M. L., Bess, R. S., Agel, J., \& Swiontkowski, M. F. (2003).Outcomes after treatment of highenergy tibial plafond fractures. JBJS, 85(10), 1893-1900.

Saw, A., Sallehuddin, A. Y., Chuah, U. C., Ismail, M. S., Yoga, R., \& Hossain, M. G. (2010). Comparison of fracture patterns between rural and urban populations in a developing country. Singapore medical journal, 51(9), 702.Available at https://pubmed.ncbi.nlm.nih.gov/20938610/ Accessed on 25/7/2021. 
Sayed, M. A. E., Mohammed, M. A., Mostafa, K. M., \& Desouky, A. A. (2019). Effect of Nursing Management on Pin Site Infection Among Incidence Patients with External Fixators. Assiut Scientific Nursing Journal, 7(16), 148-156.

Shah, K. N., Johnson, J. P., O'Donnell, S. W., Gil, J. A., Born, C. T., \& Hayda, R. A. (2019).External Fixation in the Emergency Department for Pilon and Unstable Ankle Fractures. JAAOS-Journal of the American Academy of Orthopaedic Surgeons, 27(12), e577-e584.

Sud, A., \& Ranjan, R. (2018). Textbook of Orthopaedics, -E-Book. Elsevier Health Sciences. Available at https://books.google .com.eg

/books?hl=en \&lr=\&id=EB5tDwAAQBAJ\&oi $=$ fnd \&pg=PP1\&dq=Sud,+A.,+\%26+Ranjan, + R.+(2018):+Textbook+of+Orthopaedics,+-EBook.+Elsevier+Health + Sciences. Accessed on $15 / 3 / 2021$.

Suresh, K., Sharma,S., Jogindra, V., Indarjit,W. \& Ramesh ,S.(2008). The effect of smoking on pin site infection rate among patients with external skeletal fixation. Nursing and Midwifer y Research Journal, 4, (2),71

Tucci ,G., Romanini , E., Zanoli ,G., Pavan ,L., Fantoni, M. \& Venditti M. (2019). "Prevention of surgical site infections in orthopaedic surgery: a synthesis of current recommendations" European Review for Medical and Pharmacological Sciences 2019; 23(2), 224-239.

Velazquez, R.J.; Bell, D.F. and Armstrong, P.F. (2015). Complications of use of the Ilizarov technique in the correction of limb deformities in children. J Bone Joint Surg, Wolters Kluwer Health, 75: pp. 1148-1156
White, L.; Duncan, G. and Baumle, W. (2013). Medical - Surgical Nursing: An Integrated Approach, 3rd ed., Delmar, Cengage Learning. USA, pp. 930-940

Williams, L. S. and Hopper, P. D. (2011). Understanding Medical Surgical Nursing, 4th ed., F.A. Davis, Philadelphia, pp. 1060-1070

Wong, M.E.; Chan, W. and Chair, S. (2010). Effectiveness of an educational intervention on levels of pain, anxiety, and selfefficacy for patients with musculoskeletal trauma, Journal of Advanced Nursing, 66 (5): pp. 1120-1131. Xing, J., Sun, N., Li, L., Lv, D., Geng, S., \& Li, Y. (2020). Factors influencing self-care in outpatients with external fixation in China. Journal of International Medical Research, 48(2), 0300060520902603 
تأثير الإرشادات التمريضية فيما يتعلق باستراتيجيات الرعاية الذاتية للمرضى الذين يعانون من ثثيث الهيكل العظمي الخارجي

روان محمد السيد مرسى- هاله عبدالسلام شتا- رشا فتحى محمد

التثبيت الخارجي هو إدخال جراحي للمسامير من خلال الجلد والأنسجة الرخوة إلى العظام. يتم

إرفاق إطار خارجي معدني بهذه المسامير وهو مصمم لإبقاء الكسر في محاذاة مناسبة لحدوث الالتئام و الثفاء. ولذلك تحدث قصور الر عاية الذاتية عندما يتم تثبيت جزء من الجسم. لذلك هدفت هذه الدر اسة الحالية إلى تقييم تأثير الإرشادات التمريضية فيما يتعلق باستراتيجيات الرعاية الذاتية للمرضى الذين يعانون من تثبيت الهيكل العظمي الخارجي. وقد أجريت الدراسة في قسم العظام والعيادات الخارجية بمستشفى جامعة بنها على هه من مرضى الكسور ولديهم مثبت خارجى. حيث كثفت النتائج عن نقص الرعاية الذاتية للمرضى و ايضا مستوى المعرفة لدى المرضى. من ناحية أخرى ، عانى معظمهم من ألم شديد بعد الجر احة. كما أوصت الدراسة بأهمية إعداد برامج تعليمية وتدريبية مستمرة للمرضى الذين يعانون من التثبيت الخارجى لاكتساب وتطوير معلو ماتهم وممارساتهم فيما يتعلق باستر اتيجيات الر عاية الذاتية. 